\title{
Paternity leave in Québec: between social objectives and workplace challenges
}

\section{Valérie Harvey \& Diane-Gabrielle Tremblay}

To cite this article: Valérie Harvey \& Diane-Gabrielle Tremblay (2018): Paternity leave in Québec: between social objectives and workplace challenges, Community, Work \& Family, DOI: 10.1080/13668803.2018.1527756

To link to this article: https://doi.org/10.1080/13668803.2018.1527756

册 Published online: 02 Oct 2018.

Submit your article to this journal 중

View Crossmark data $₫$ 


\title{
Paternity leave in Québec: between social objectives and workplace challenges
}

\author{
Valérie Harvey (D) a and Diane-Gabrielle Tremblay (1D ${ }^{b, c}$ \\ ${ }^{\mathrm{a} D o c t o r a l ~ S t u d e n t ~ o f ~ S o c i o l o g y, ~ L a v a l ~ U n i v e r s i t y, ~ Q u e ́ b e c, ~ C a n a d a ; ~}{ }^{\mathrm{b}}$ Labour Economics, Innovation and Human \\ Resources Management, TELUQ, University of Québec, Québec, Canada; 'CURA- WAROL (Community- \\ University Research Alliance on Work-life Articulation Over the Lifecourse), TELUQ, University of Québec, \\ Québec, Canada
}

\begin{abstract}
Since 2006, fathers in Québec (the French-speaking province of Canada) have had the right to 5 weeks of non-transferable paternity leave, as well as the right to take an additional 32 weeks of leave that must be negotiated with mothers, under the Québec Parental Insurance Plan (QPIP). We describe the positive impacts of this important public policy and explore the challenges that await in the future application of the QPIP. By combining the results of two series of interviews that studied Québec fathers' use of parental leave, we portray tensions experienced by fathers in the companies they work for. Our research shows that some fathers encounter opposition and important challenges in their work environment if they choose to go beyond the five weeks of non-transferable paternity leave. While we found that fathers will sometimes force their employers to accept the duration and timing of leave that best suits the fathers' families, some fathers are obligated to negotiate leave terms and are forced into a compromise in order to keep their reputation as 'good' employees.
\end{abstract}

\section{RÉSUMÉ}

Le Québec est, à l'exception notable des pays nordiques, le seul endroit au monde où un généreux congé de paternité non transférable est offert. Le taux de participation des pères québécois aux congés parentaux est le plus élevé du Canada grâce au Régime québécois d'assurance parentale (RQAP) implanté en 2006 et qui inclut le congé de paternité dans son programme. Dans cet article, nous présenterons les impacts positifs de cette politique publique et explorerons les défis qui restent à franchir pour le RQAP. En combinant les résultats de deux séries d'entrevues avec des pères ayant fait usage du congé parental au Québec, nous exposerons les tensions qu'ils expérimentent dans leur couple et au travail. Si la présence du père près de son bébé naissant est parfois étiquetée comme une " mesure préventive » contre les troubles de comportements, cela permet également à l'enfant de développer une vision plus égalitaire des rôles parentaux. II y a plusieurs incitatifs possibles aux pères qui voudraient s'impliquer davantage, toutefois notre recherche démontre que certains d'entre eux feront face à de

\section{ARTICLE HISTORY}

Received 19 June 2017

Accepted 5 September 2018

\section{KEYWORDS}

Paternity leave; Québec; work-family balance;

parental leave

\section{MOTS-CLÉS}

Congé de paternité; Québec; conciliation travail-famille; congé parental 
l'opposition et que d'importants défis se dresseront dans leur environnement de travail s'ils choisissent d'utiliser plus que les cinq semaines offertes par le congé de paternité. Alors que plusieurs pères exigeront que leur employeur respecte la planification et la durée du congé dont ils ont besoin, d'autres négocieront et seront forcés de faire un compromis dans le but de continuer d'être perçus comme de « bons » employés.

During the twentieth century, the demands of women led to the implementation of many public policies aimed at correcting historical inequalities between men and women. The measures adopted by the Quebec government made it possible to catch up with other societies: the right to vote (1940), legal capacity (1964 and 1977), the Divorce Act (Government of Canada, 1970), the legalization of abortion (1988) and the Pay Equity Act (1996). These and other measures have allowed women to leave the domestic sphere and access not only financial autonomy but also moral autonomy through several new rights: fertility control, divorce and direct access to family allowances.

Although equality between men and women is embodied in the laws of several countries, statistics show that in practice, it is not necessarily ensured. Since 2012, the ratio of the average hourly wage of women workers in Quebec is $90 \%$ of that of men (Institut de la statistique du Québec, 2017, p. 26). In addition, Quebec women often have multiple tasks in their roles as career women and mothers. They still are the main persons responsible for household chores. These tasks create tensions that are added onto the shoulders of these 'superwomen' who seek to combine their careers with family life (Conway, 2003). While policies have aimed at improving the situation by giving women rights that are in principle equal to those of men, it seems that this has not been enough to ensure effective equality between men and women. Esping-Andersen (2009) does not hesitate to refer to this situation in terms of an 'incomplete revolution'.

In order to achieve more equality between men and women, certain public policies need to be addressed directly towards men. This is precisely what the province of Quebec did when it modernized its parental leave policy in 2006. The Québec Parental Insurance Plan (QPIP) now reserves weeks for the father, which should contribute to more equality in the arena of parental responsibilities. However, we are beginning to see the consequences that result from long parental leaves in the context of today's competitive career market. Indeed, despite a favorable social climate, Quebec parents are still facing challenges when claiming their rights in the workplace, and this now applies not only to women but to men.

With the objective of contributing to the understanding of these challenges, this paper addresses the important topic of equality between men and women through the lens of paternity leave. First, we present the idea of paternity leave as a progressive measure, documenting its effects on child development and gender equity. We then build on Ulrick Beck's theory, which is the theoretical foundation of our questions. From there, we present the Quebec policy for parental leave. Finally, we discuss an insight into fathers' experience of parenting (based on 57 interviews of fathers), work-family balance and also the career consequences of returning to work after a parental leave. The paper contributes to an understanding of the systemic and pervasive inequalities related to gender and family roles. 


\section{Paternity leave: a progressive measure?}

Fathers' involvement in early childcare has been found to have several positive consequences, which explains why policymakers have enacted parental leave specifically for fathers. These consequences include positive behavioral outcomes for children and increased sharing of childcare and housework by parents. Since the 1990s, a variety of studies have examined the consequences of a father's increased presence for his infant. Some work identifies the specific consequences paternity leave can have. According to a Swedish study, for instance, a longer paternity leave makes it possible for fathers to spend more time with children when children are older, leading to a reduction in his working hours after leave (Haas \& Hwang, 2008). Nordic children who have benefited from privileged contact with their fathers in early childhood have better academic results (Gíslason \& Brandth, 2012). A longitudinal study in England also indicates that babies, especially males, who interacted frequently with their fathers during their first three months, had fewer behavioral problems: 'More specifically, paternal sensitivity and warmth in interactions has been demonstrated to predict a lower level of behavioral disorder much later in childhood' (Ramchandani et al., 2012). For girls, the father's presence facilitates better self-esteem (United Nations, 2011). In research circles, these results indicate that the involvement of a father with his baby is a 'preventive' measure which is effective against future problems (Ramchandani et al., 2012).

When Swedish fathers take long parental leaves, they tend to continue to share tasks equally thereafter (Haas \& Hwang, 2008). A better balance between Icelandic parents has long-term consequences on the perception of gendered roles by the child: '[...] it is believed that the pedagogical effect of children observing both parents participating in caring and chores around the house contributes to increased gender equality in the longer term' (Gíslason, 2007). Parental leave also appears to have positive implications for the division of labor at home. If the father is present in the early life of the child, domestic tasks seem to be shared more equally afterwards (Tanaka \& Waldfogel, 2007). Icelandic parents who took advantage of the generous parental leave implemented in 2000 reported a better sharing of household tasks than parents in 1997. The participation of fathers at home increased by 30\% in 2005 to 40.4\% in 2010 (Gíslason, 2011). The involvement of the father is also important for the dynamics of the couple, as it facilitates women's ability to pursue careers while both assume their share of the parental role; however, this paradoxically increases the stress due to work-life balance (Lamb \& TamisLemonda, 2004) as women tend to assume a larger share of domestic chores at home, even if they are in the labor market.

There has been little research on the impacts of leave-taking for fathers, since few countries have non-transferable leave for fathers (the Nordic countries and Quebec essentially), and fathers remain marginal in the work-family literature There has been an increase in studies examining gendered roles and also the flexibility stigma for fathers. For example, Williams, Blair-Loy, and Berdahl (2013) have shown that while flexible working hours, compressed hours and flextime have been around for decades, their use has not increased that much. These authors indicate that this low usage can be linked to fears of negative career repercussions, more the case for men than for women, as women tend to take advantage of these types of flexibility more than men. While their research is not on paternity leave per se, Coltrane, Miller, DeHaan, and Stewart (2013) 
show that if men reduce their working hours, they can experience a 'flexibility stigma' which leads to a reduction in earnings and more limited career opportunities in the future. In the same vein, Rudman and Mescher (2013) show that men who take a family leave have a greater propensity to be considered poor organizational citizens and thus as not meriting such a leave. Male leave takers were considered to possess feminine traits (weakness and uncertainty) and on the contrary not as strong on traditional male characteristics, such as competitiveness or ambition. This is said to put men more at risk of negative career impacts, such as downsizing or being demoted. Only Rudman and Mescher's research is specifically related to leave-taking, pointing to its negative effects and perceptions from managers and employers alike. In line with Rudman and Mescher's research, through interviews with 35 managers, Daverth, Cassell, and Hyde (2016) have studied managerial discretion in work-family matters and work-life balance. They show that while organizational justice and fairness are taken into account in managerial decision-making, this decision-making is influenced by gender role beliefs of managers.

\section{Theoretical perspectives}

Our theoretical perspective for research on parental leave, family and work-life issues is the work of the sociologist Ulrich Beck. In our view, this makes it possible to situate the changes brought about by the QPIP in the more general societal context and to better understand the issues and challenges fathers and mothers are confronted with in the present socio-economic context. Beck situates the nuclear family of the early twentieth century in the context of what he calls 'simple modernity'. In this approach, the family is an institution based on a division of complementary roles, according to gender; each partner is affected to a specific task, the family or work outside the family sphere. This role division is considered by the author as necessary in the context of the industrial society (Beck, 1992). However, in a society based on advanced modernity, in which we live today, families become burdened by conflicts that prevent individual members from fully exercising the principles of freedom and equality that are put forward by this society (Beck, 1992). Indeed, despite the fact that women now have access to the same education as men and are widely present in the labor market, inequality persists. Women are still responsible for most household and childcare tasks and often have to give up a share of their income to succeed in combining work and family, which can lead to impoverishment after a divorce and/or retirement. The number of people living alone is constantly increasing and for Beck, this is not surprising since a globalized society favors the individual living alone. Beck considers that families and couples have become an anachronism, the individual having to break away from any relational, conjugal or family 'liability' (Beck, 1992). By requiring free, available and mobile individuals, advanced modernity creates tensions in terms of time and roles between family members, who then try to manage these tensions.

For Beck, there are three solutions to reduce these tensions between work and family. The first one is a return to the traditional family, thus a crystallization of the division of tasks according to traditional roles. There is also the possibility of creating a society for 'ultra-mobile singles', yet with the result of drastically reducing the number of births in a country. The third solution described by Beck proposes public policies coming from the population, allowing couples to create their individual terms of use (Beck, 1992). 
Family policies put in place in many countries can contribute to this third solution. Including the father in domestic and parental tasks can perhaps reduce inequalities between men and women. The principles of freedom and equality of both partners are thus put into tension.

The QPIP was created in a society suffering from a decline in birth rates for many years, and where women were manifesting a difficulty to manage work and family (Tremblay, 2012, 2014). Quebec policymakers thus wanted to help parents to better articulate work and family needs as well as to increase the fertility rate and increase gender equality, which was requested by women's groups as well as women's committees in unions. Policymakers were thus compelled to introduce important changes to the previous federal parental leave program, especially in relation to supporting fathers as caregivers (Doucet, McKay, \& Tremblay, 2009). Some years after the introduction of the QPIP, our research set out to determine to what extent fathers' experience of parenting and leave-taking was indeed positive for them, including the career consequences of leave-taking.

This article thus addresses the following questions: What are the most frequent tensions experienced by fathers when they use the weeks of parental leave that are allocated to them? How did they negotiate their leave with the employer? How was the return to work after parental leave? These issues appear to have created new challenges in the workplace, and can lead to some important negotiations between employers and employees. By focusing on the testimonies of fathers, we explore the tensions experienced by fathers with their employers as they attempt to reconcile work and family responsibilities.

\section{The Québec Parental Insurance Plan (QPIP)}

Since 2006, Quebec has had a parental insurance plan which is different from the rest of Canada (Tremblay, 2014). Two options are available in the QPIP: the so-called basic and special plans. Fathers who take paternity leave for three weeks receive $75 \%$ of average weekly earnings (special plan), while those who take five weeks receive compensation at $70 \%$ (basic plan), up to an earnings ceiling of $C \$ 71.500$ [€51.395] per year in 2016. Self-employed fathers can also benefit from the policy if they have earned at least $C$ $\$ 2000[€ 1.468]$ in the 52 preceding weeks. Quebec is still the only province in Canada to provide fathers a specific paid paternity leave, which leads to impressive statistics: in Quebec, only 20\% of fathers used the Canadian parental leave before the reform; since 2006, 80\% have taken the QPIP for an average of seven weeks, which combines the total length of the paternity leave (five weeks) along with two weeks on average taken from the parental leave that parents can share (Tremblay, 2012 and QPIP data).

QPIP data indicate that $88.3 \%$ of parents used the public program in 2015 (Conseil de gestion de l'assurance parentale, 2016). They also indicate that the majority of parents combined maternity/paternity and parental leaves (68\%). In $22 \%$ of cases, the mother was the only user for both maternity and parental leaves; and in $11 \%$, it was the father who alone took paternity and parental leaves.

The data from QPIP show that mothers take all their maternity leave (special plan of 15 weeks or basic plan for 18 weeks) while fathers take all their paternity leave (3/5 weeks). It seems that both parents consider it natural to take the leave specifically planned for them (maternity/paternity). But when we look at the parental leave data, the traditional arrangement is evident: for $74 \%$ of the couples, fathers took only the paternity leave (three or five 
weeks) without taking any of the parental leave. When fathers combine their paternity leave with some weeks of the parental leave, they took an average of 13 weeks (Conseil de gestion de l'assurance parentale, 2015). According to the most recent Employment Insurance Monitoring and Assessment Report (2017) which covers the whole of Canada, outside of Quebec only $11.9 \%$ of recent fathers took or intended to claim parental leave in 2015, compared to $85.8 \%$ of fathers in Quebec. It is clear that the QPIP had major effects on the behavior of fathers in Quebec.

A survey done by the QPIP indicated that fathers' main motivation for taking the paternity leave is to help the mother (56\%). The child is also a strong reason: to know the child and take time with the newborn is often cited (33\%) as well as to care for the baby (27\%). Fathers were asked why they did not take parental leave and they mainly answered that it was because the mother uses it (70\%). Fathers who take all the parental leave are rare $(2.4 \%)$, these fathers said they did so because the mother was a student (so she could not take the parental leave), that she did not work or had to return to her job. So even for the fathers who took the longest leave from work, the reasons are often linked to the mother's inability to take this leave (Zins, Beauchesne et associés, 2014).

Also, in the media, the new term 'bosspartum' has appeared. It describes executives who now hesitate to hire young women for a job because they do not want to manage the replacement induced by the maternity/parental leave if she becomes pregnant. Since the addition of 32 weeks of parental leave, that can go along with the 'real' maternity leave (18 weeks): 'An insidious setback is emerging: bosses are considering to advantage male candidates when they hire, just to avoid the thorny management of maternity leave' (Forget, 2011). It is apparently expected that men won't take much leave. It is difficult to assess the percentage of employers who are not hiring a woman for fear of a possibly long maternity leave which usually follows the arrival of a child. This discrimination is virtually impossible to denounce and is exercised against all women in childbearing age. It is a surprising consequence when we consider the low fertility rate, only 1.62 in 2014 (Conseil de gestion de l'assurance-parentale, 2016), which means the maternity leave will not take-up so much of a woman's active working life because of reduced family size. This is why it is important to determine what are the major challenges and adaptations fathers have to overcome to take a paternity or parental leave. More specifically, we wanted to examine the return to work of fathers who used leave after the birth of their child.

\section{Methodology}

Given the paucity of research on the subject, we chose to do an exploratory, qualitative study. We combined the results of two series of interviews that investigated fathers' use of parental leave in Quebec. The first set of interviews was conducted in various employment sectors (including education, public service, manufacturing) and tried to understand the experience of 26 fathers who took at least four weeks of leave, home alone without the mother, who had returned to work. We used an open-interview approach and general questions focused on fathers' experiences while on parental leave with their child, on the history of the negotiation of the leave with the employer and impacts upon returning to work. The interviews lasted between one and one hour and half, and were conducted outside the work site. 
In the second set of interviews we decided to focus on a specific sector, and more specifically a predominantly male employment sector, that is computer and video game companies (IT sector), in order to look at the impact of parental leave in a maledominated sector. Recruitment emails were sent by companies who were interested in this research. Interviews were structured around general themes, or large questions, to make it possible to explore new subjects as the interview went on. To participate, fathers had to have used a minimum of three weeks of the QPIP program. A total of 31 interviews were conducted, outside the company site. The IT sector was chosen because the challenges faced by fathers working in a male-dominated company are numerous: high pressure, overtime, frequent crunch times to finish a project. The 31 fathers who were interviewed had used a minimum of three weeks of the QPIP leave, some had taken leave more than once for different children. Two categories were observed: fathers who preferred to take a short leave, and fathers who wanted 'a longer vacation' as they sometimes call it. Of the 49 different leaves taken by the 31 fathers, 21 were rather 'short' (mean of 5.1 weeks), while 29 leaves were 'long' (mean of 17 weeks off). Long leaves required more adjustments from the father and the company, as we will see later.

In both cases, the interview guide included the following questions: Was there a negotiation with their employers? What are the main difficulties encountered at work after the paternal leave? Has paternal leave changed their view of family and work? What were the professional impacts of taking the leave? How did they manage the leave, as a special kind of vacation or did they keep contact with the company? We chose the method of thematic content analysis (Bardin, 1993; Savall \& Zardet, 2004) for the analysis of the interviews, and did manual thematic coding, without any specific software. The interviews were divided according to the themes and questions of our interview guide, but a few new themes also emerged during the interviews. We focused on the quotes that we believed were more significant and characteristic for each theme and thus collected what Savall and Zardet (2004) call 'typical quotes'. The main themes are the following: take-up of leave, negotiation with the wife or partner, negotiation with the employer, relations with work colleagues, timing and length of leave, perceived impacts on their career.

\section{Results}

\section{Paternity leave: do not disturb!}

In our interviews, many fathers said they did not have to negotiate their leave requests because 'it is a right' to take leave. However, there were cases when the employer questioned the existence of his obligation to authorize the leave and the employee had to prove that it was indeed a legal right. While some men did not need to negotiate the leave itself, they did need to negotiate the timing and length of leave. The company or supervisor typically indicated that the timing of the leave was not convenient for the company and the new father had to make a compromise by dividing the weeks or taking them later, when it was more convenient for business (e.g. during the slow season).

When she was 12 weeks pregnant, I told my employer. The problem was my departure date. (Marc-Olivier, 2 children, 18 weeks' leave for the last child) 
If the leave to be taken was longer than the five weeks of paternity leave, that is including part of the parental leave shared with the mother, fathers sometimes had to justify this longer leave and to search for a replacement and train the new recruit.

When we had the discussion about my leave, my manager told me: 'You take your five weeks, it's enough, right? After two weeks, your wife will be back in shape.' I said: 'No, my wife really needs my help.' So he told me: 'If you take longer leave, it will be difficult to find a replacement and it will take a long time to train the person.' After my first five weeks, I came back to work and stayed two months, the time needed to train the new person before I went off again on leave. (Pierre-Louis, 2 children, nine weeks off for the last child)

Sometimes the employer thinks the father is only entitled to five weeks and tries to reduce the duration of the leave by indicating the difficulty he would encounter in finding a replacement.

When I discussed this with my immediate supervisor, the information was not welcome because he immediately thought about my replacement. It was not easy because he said that I had the right to take only five weeks as a father. They had to search in the law and regulations to realize that yes, I was entitled to take longer. (Simon-Pierre, 2 children, 31 weeks for the last child)

Some employers asked that the father of a newborn retain a connection with the job, especially by email, or sometimes by coming into the office occasionally. Some go as far as to provide support to the work team from home:

For the second one, I had to...I was available for two months because it was a bit stressful that I was not there in the summer. So they gave me a cell phone and I became a support. I accommodated them. It is because we are not many doing this job, so there are some positions that are more strategic, including mine. It made them feel safer to know I had a cell phone and could answer in case of need. (Gau, 2 children, 12 weeks' leave each child)

In most cases, fathers tend to follow emails and eventually intervene if an issue comes up; most fathers seem to consider this normal, and they often justify this by not wanting to be drowned in emails when they return to work:

I stay connected all the time on my emails, but ... barely. It was more a matter of following emails a little. Giving answers to what was really important, but it did not really monopolize that much time. Like I do during my vacation and stuff like that, but in a very passive way. Instead of responding to emails directly, I'll put a little reminder to answer, a little trick like that, just not to be drowned when I come back. (Faris, 2 children, 9 weeks' leave each child)

A lot of fathers seem to accept this obligation to consult and sometimes answer emails while they are away, as Faris demonstrated. A common practice while on vacation, they saw the childcare leave in the same way. However, it can be different for others, especially if the employer asked for more than emails:

For the first child, I had a part-time arrangement, but for the second, they preferred that I do telework. I was at home but I was supposed to work. The hours were not calculated. The problem was with the clients. I could not explain the situation to them: 'I am not able to answer your requests as quickly as usual, because I am on paternity leave, and I am also working!' For my clients, it was hard to understand. It put me in a difficult situation. My reputation took a hit. (Vincent, 3 children, 24 weeks' leave for the last child) 
Some colleagues were suspicious about long leaves, as if the employee's absence could impact negatively the future of the company:

Colleagues reacted as if it was a punishment that I inflicted on the boss, that was the opinion of my colleagues. There was a lot of pressure on me. They said: 'Look ... Try to come back sooner, do not take it all, you'll earn only $75 \%$ of what you usually earn, can you live with that?' It was a way to influence the employee to return quickly or as soon as possible. (Simon-Pierre, 2 children, 31 weeks for the last child)

One father mentioned that when the time of his departure for leave arrived, he experienced a feeling of unfairness because a maternity leave departure is always a festive event, often with a party in the workplace while the father's departure is not celebrated. He perceived this situation negatively, as if he was not recognized as a parent, unlike mothers whose parental role is clearly recognized and seen positively in the workplace.

I'm in an environment where there are a lot of pregnancies at work so leaves are a regular situation. Most of the time, women organize small parties for their colleagues' departure and we are also happy when they return. For men, leave is rare, so there is no party, people are happy but it's not like for the mother who is leaving and will spend time with her child. It's just a different situation for the father. (François-Xavier, 3 children, 25 weeks' leave for the last child)

\section{Return to work after the leave: not always so easy!}

We asked the fathers about whether their return to work was easy and smooth. The results varied greatly. In our interviews, the majority of fathers had a good experience when they returned to work, especially if the leave was short (three to five weeks), as $89 \%$ of fathers' leaves in this study are. For some fathers who experienced a positive return to work, the leave was an opportunity to become a role model for other fathers to take leave at their workplace.

One said, 'Man, you're my model, I took three months off because of you! I heard about you, that you'd taken many weeks.' This was the first time I heard that there was talk about me, that there were rumors about my leave! He said: 'I took three months off because you had taken six months.' (Marcus, 2 children, 24 and 28 weeks of leave)

In the first series of interviews, where fathers had spent at least four weeks with their children, only one father mentioned big challenges related to his career after the leave. In the second series of interviews which involved fathers in jobs related to computers and video games, more fathers mentioned tensions occurring after they returned to work; some even resigned from their job. When a replacement is hired, this can create conflicts and unpleasant surprises when it is time to come back. The computer and even more so the video game sector are sectors with tight deadlines, with more male workers, and this may make the situation more difficult and challenging for fathers. Employers clearly seem to be less supportive in the IT sector than in other sectors (Moen et al., 2016), although there were also negative experiences in other sectors (Tremblay \& Mascova, 2013, 2015).

Yes, it had an impact; if I had not taken leave, the employer would not have hired someone to replace me. The person who replaced me did not take my place but he's not a good person, nobody gets along with him, me neither, and then it created conflicts at work. I have not really 
been victimized, but with that new person in the firm, it was hell of a time for me. (Paul Simon, 3 children, 13 weeks leave for the last child)

\section{New skills for fathers}

The experience with the child allowed fathers to develop new skills that helped them in the workplace, including communication and prioritizing. In our interviews, many fathers were very vocal on this issue, indicating they had developed their emotional side, become more compassionate and more attentive:

I am more attentive to people in general. Especially at work, people ask me questions and I am more inclined to answer. I see myself more as a caregiver, at work and even with my friends. There are many people who ask me questions and I like to answer them. Before the leave, I was more distant from all that, I think it helped me to become a caregiver. (Léo-Paul, 1 child, 16 weeks on leave)

Many fathers indicate they learnt a lot from taking care of their child, amongst other things how to establish priorities:

The child is one of our best coaches because he has no ulterior motives, his needs are clear, you really have to listen to him. The parent has unsuspected energy reserves! So it allows us to relate to others, to realize what it is more important, a good thing to manage the priorities.

(Cid, 1 child, 15 weeks on leave)

Taking non-transferable paternity leave can thus bring about positive impacts for fathers in the work environment, such as being a positive role model, developing a more compassionate and understanding attitude with colleagues and being better able to establish priorities. Many of these fathers mentioned that this gave them a new perspective on their work environment and changed their attitude towards work and colleagues.

\section{Short term negative impacts in order to reach equality in the long term?}

As many mothers already experience when they take time off or ask for working time arrangements in order to care for their children (Tremblay \& Mascova, 2013), our research also shows that there were some negative career impacts for fathers as well. When promotions come up, long periods of leave can be an obstacle. In this context, the number of years of experience counts.

At work, we have annual reviews, if you take a leave of six months, you don't have such a good evaluation. The boss doesn't know what you did. In a three-year project, I left a little before the end. An email was misinterpreted, just before my leave, I had no feedback on it, I had a beautiful leave, but six months later I hear: 'Oh yes, this email then, it was not good ... Here you have some blame for that.' I felt as if they used my leave to delay the talk about that email and the whole situation. Because of the leave, I did not have that information earlier, and it has affected my career ... If I'd been able to talk about it ... "You could have told me about it, it was six months ago! I would have explained this email which was misunderstood, blah blah blah. I would have apologized for the email...' This is the only fault they found in my work, and it was during the parental leave. It may be a coincidence ... (Marcus, 2 children, 24 and 28 weeks of leave)

Although it is not obvious to link extended parental leave with missed career opportunities, some fathers wondered about this and clearly, they found that the leave could have an impact in slowing down their career: 
I saw an opportunity that was really interesting for me, but I was not sure l'd qualify in terms of years of experience due to the leave. It could have an impact at this level, but I don't regret the leave ... but in my job each year counts so it is sure that my paternity leave slowed my career a little. (William-Junior, 3 children, 52 weeks leave with the second child, nine weeks with the last)

I think my leave penalized me. There are things that I cannot explain myself, coincidences that are, well, bizarre, which may be related to that ... to my life choices, I don't know. It was details, but ... It's been several years since I asked to have a bilingual bonus. Normally, when you occupy a position that requires you to speak French and English, if you have a good level in your second language ... It seems obvious to me that my position meets these criteria and that I also fulfill the requirements. But they never responded to my requests. (Vincent, 3 children, 24 weeks' leave for the last child)

For some of these new fathers, the return to work was not easy because of that and it led them to go as far as to look for a new job and eventually leave the company, even if they had liked their job up to that point, before the leave.

Upon my return, I had the impression that those we put on this project, it was the people who had less experience, or those we don't want to see on the big projects. So it was hard for me, it was a kind of demotion. I felt like I was punished. That situation has led me to seek another job and to leave a job I loved. And the company simultaneously has lost an experienced employee because I had five years of experience, and for a video game company, I was an asset. I had the ability to make a substantial contribution, but the problem is that I was not ready to do so outside of normal hours. (Abel, 2 children, 38 weeks of leave for both)

In fact, amongst the 31 fathers met in the IT sector, 4 had changed jobs, 2 spoke about demotion (with the feeling of having missed a promotion because of their leave) and 2 others were thinking about leaving the IT sector. It was especially true if the father had taken a 'long' leave (more than five weeks). The IT sector clearly presented more difficult and challenging situations than other sectors such as education, public service or even manufacturing, possibly because these are more unionized sectors than IT. So, even if fathers who took a leave in the first year after the birth of their child are numerous, they can face challenges after their return at work (Harvey \& Tremblay, 2018).

\section{After returning to work, more need of family time}

Some fathers who had taken extended parental leave and returned to work while continuing their involvement in caregiving felt that they needed more time for their family, more than their colleagues, so they refused to do extra hours on evenings or weekends. In some cases, this was an issue with colleagues and employers or supervisors, as these persons had previously not put limits on their working time, and now wanted to do so. This sometimes caused difficulties, one father even saying he started lying to cover up for the time off.

The interpretation of my current boss is different from that of my previous boss. The employee is subject to more tensions and feels compelled to lie to continue to take time off ... Eventually, this can lead to a change in position ... My child, he has PDD (pervasive developmental disorders). For the past two years, I have had to take several days off. My previous boss was very understanding. He protected me. It was great. But now I have someone else who does not know me well: 'Oops! What are you doing? You're always taking time off! This is bad ...' It caused me a LOT of problems. I lie now. I say that I was at work when I was not. That 
is really problematic. No kidding, that's really problematic. (Marcus, 2 children, 24 and 28 weeks of leave)

When I returned to work my workload was very heavy, no one had replaced me during my absence and I had no colleague to share the work. My request for days off was denied: 'Why don't you take your summer vacation?', they said. But I could not wait for the summer, I was very tired. In fact, a few weeks after I started working I experienced burnout. It is certain that after taking this leave, to my boss I was an absolute traitor. They tried to relocate me somewhere else. When the person hates you because you take a paternity leave, she is determined and wants your skin. It's a bit like being accused of sexual assault: even if the person did not do it, everyone always has a doubt about him even if the employee is good. (Samuel-Leo, 2 children, five weeks on leave for the last child)

Fathers returning to work after parental and paternity leave clearly have to face challenges as they often don't have the same availability for extra working hours and this is often seen negatively by colleagues and employers. While it is accepted for mothers to be more childand family-oriented after a birth, it is expected of fathers that they return to the previous situation, which is often one of long hours and presenteism. Fathers are expected to overinvest in work and underinvest in the family, while mothers are expected to overinvest in family and underinvest in work (Tremblay, 2012).

\section{Discussion}

Our interviews suggest that generally, the 5 weeks paternity leave was well accepted. However, a father who wanted to take more (as it is possible to take-up to 32 additional weeks of parental leave) took more risks because parental leave can be perceived negatively as some kind of 'vacation', which brings the company to find a replacement. After one year of parental leave, the return can be harsh for the father. The person hired to do their job while they were absent had the time to become well integrated into the team and the company; some potential promotions may have been passed up during the leave; bonuses and other advantages can be declined to a newly returned parent who has the reputation of being less engaged and involved in the success of the company.

Consequently, parental leave also has an impact on parents' priorities. A working parent knows that a child at home will sometimes be sick or will need to go to a regular checkup. It is one of the major problems when fathers return to work: they cannot be as present as when they were on leave, and this is particularly the case for fathers, as expectations at work have not changed because they are a father. Caught between their work and their parental obligations (child's illness, kindergarten schedules, etc.), parents live a daily tension which can degenerate and lead to conflicts (Carlson, Kacmar, \& Williams, 2000), and a certain number of parents, including fathers, will choose to resign from their job and their company for a position where there are fewer expectations or less weekly hours of work (Harvey \& Tremblay, in press).

New fathers typically take a shorter leave than the mother, but this does not mean that they can avoid tensions at work. Are inequalities still conveyed through education, social environment and workplaces transferred to the fathers who want to be more involved in the 'care' role, an area usually under the responsibility of women? In an advanced modernity context, which requires that each person or employee be free and available, the child can be seen as a 'liability', as Beck (1992) has mentioned; this has an impact not only for the 
mother, but for the engaged father as well. This may be a form of motherhood discrimination extended to a parental discrimination.

While the five weeks' paternity leave has become an accepted standard in Quebec, our research has shown that it may also cause difficulties in the work environment, with some colleagues and supervisors considering the father to be 'on vacation' for too long. Assuming a role usually reserved to the mother, our results show that the father can be labeled as a junior employee who is less involved in his work and less available or, as mentioned by Rudman and Mescher (2013), a poor organizational citizen. Promotions and opportunities to advance in his career can be reduced for this reason and it is thus understandable that fathers voiced they feared negative impacts on their career, trying to limit the 'flexibility stigma' (Coltrane et al., 2013). Some employers do not hesitate to put pressure in order to ensure that the leave will be taken at times convenient the company. Such an attitude can lead to frustration and encourage some fathers to leave their job.

Some fathers were willing to abandon the idea of taking a longer leave if the employer had disagreed, not to 'cause trouble', as some participants indicated. The employer and the immediate supervisor's support seems to be very important, as was observed in other research: indeed, the attitudes of the superior and the weak organizational support are present in sectors such as law, and make fathering particularly difficult and challenging (Tremblay \& Mascova, 2013). Williams et al. (2013) have shown that fears of negative career repercussions lead fathers not to use flexible working arrangements which may be available to them. We also observed that some fathers chose to leave their job and look for another work environment where balancing work and family might be easier.

In order to minimize the inconvenience of such an unexpected absence, fathers who had taken long leaves sometimes had to make arrangements that go beyond the technological link between the company and the home. Some had telework or part-time work arrangements, which was not necessarily positive, given the stress and failure to fulfill all obligations. A forthcoming Norwegian study, which examines the advantages and disadvantages of the flexibility of leave offered in this country, arrives at the same result:

In line with this we find that the type of flexibility that allows for taking leave on a part-time basis might have a negative effect on fathers' caregiving practices because working at the same time lets working life interrupt their caregiving and determine the organization of the leave. This often created stressful situations. (Brandth \& Kvande, 2018)

In any case, it does appear that fathers can be the object of a 'flexibility stigma', as Coltrane et al. (2013) observed, with more limited career opportunities in the future. Rudman and Mescher (2013) have also pointed to negative effects from leave-taking and negative perceptions by managers or employers. Also, Daverth et al. (2016) have shown that while organizational justice and fairness are taken into account in managerial decision-making, the process is also influenced by the gendered role beliefs of managers. Our results indicate that fathers take this into account and try to make their paternity leave as invisible as possible (taking emails, helping out from home, etc.), in order to not be seen as poor organizational citizens (Rudman \& Mescher, 2013). The challenges of leave-taking are thus important for fathers, even in a society such as Quebec, where women and men's parental rights appear to be recognized, at least in legislation. 
However, a father who wants a long leave is often the first one to ask that of his employer. As we have seen, the father who takes more than five weeks is almost always the first to do this in these organizations, where employees are quite young. He can sometimes become a model for some colleagues and inspire other fathers to take weeks of parental leave (Tremblay, 2015), but this pioneer role may also come at a cost. Paving the way for a different behavior of fathers in leave take-up is not easy for the first who do it and many fear the negative impacts on their career. In terms of gender equality, it is clear that even if there is a high participation rate of fathers in paternity leave $(80 \%)$, they are still not taking as much time as mothers. The problems encountered in the workplace concerning timing and length of leave lead them to fear negative impacts on their career. As a result, fathers tend not to take as long as they might prefer, and less time than their partners might like in order to ensure better gender equality.

Still, a longer parental involvement from the father at the birth of the child can change the employers' view regarding parental roles and reduce the pressure on women's shoulders. A part of the QPIP objective has been attained. In the future, if there is an increase in number of weeks taken by fathers, this could have a positive impact on gender equality, allowing the child to have a more egalitarian vision of parental roles (Gíslason, 2007). As for the QPIP objective of supporting natality, the data from years after 2006 indicate that there has been an increase in fertility rates (from 1.4 to 1.6), suggesting that this objective is apparently partly attained. Yet this is not the only objective, nor the main one, for many of the advocates for this new leave, for example, women's groups.

\section{Limitations and directions for future research}

Concerning limitations of the research, it is obviously not a fully representative study of fathers on leave, given the qualitative nature of the analytical approach. While this work provides interesting insights into the challenges of taking leave for fathers, it is not statistically representative. Nevertheless, 57 interviews represent an important number of respondents, especially considering a contemporary trend like paternity leave, a practice not common outside of the Nordic countries. Future research such as a survey on this issue with the QPIP representatives could lead to a more representative picture, as it is otherwise difficult to access fathers who took leave, an observation we identified in this research. It would be interesting to compare the situation in Quebec to that observed in other countries, mainly the Nordic countries. It could also be pertinent to compare the situation of men and women when they return to work after a leave, again taking into account the length of leave. A study to better understand employers' and coworkers' perspectives of paternity leave and the impact of gender on their perceptions could also be relevant.

\section{Conclusion}

Through two sets of interviews with fathers who used paternity and parental leaves of the Québec Parental Insurance Plan (QPIP), we wanted to explore the impacts of this new public policy, in particular, its influence on the lives of fathers. The fathers that we met were often very vocal about their 'right' to take paternity leave and indicated that companies are generally open to that. However, research also shows that some fathers encounter opposition and important challenges in their work environment if they chose to go 
beyond the five weeks of non-transferable leave, because they extend the duration of the leave over the time reserved for the father. While most fathers will compel their employer to accept the length and timing of leave that suits them best as a parent, some will also negotiate and compromise in order to keep their reputation as a 'good' and dedicated employee.

The QPIP, and the specific weeks for paternity leave, were seen as an incentive for fathers to assume their parental role. This leave makes it possible to develop new skills for fathers, and to gain confidence in their abilities to care for their children. Many fathers ask for more family time after returning to work. However, they sometimes face negative impacts: some saying that they were demoted, others leaving their job for a new one where it was easier to balance family and work. In a highly competitive society where individuals have duties to perform in their careers, often with numerical or financial objectives, the presence of a child obviously brings limits to an endless involvement at work. Will the sharing of parental time and responsibilities be sufficient to bring more equality between both parents? Fathers who took a long leave challenge the image of the one-year leave dedicated to the mother. They become role models for others who have the same desire. Over time, we will see if these new perceptions about the role of the father in the family will be the source of lasting changes, or if the difficulties in leave-taking (timing and length) will limit the changes.

Revisiting our theoretical perspective, Beck's theory of advanced modernity, there are three solutions that are said to reduce tensions. A return to the traditional family and a division of tasks according to traditional roles appears unrealistic in modern-day Quebec. Likewise, the same can be said for a society of 'ultra-mobile singles', individuals fully flexible to adapt themselves to requests of the workplace.

On the contrary, as we saw, fathers returning to work after leave often have to face challenges as they no longer have the same availability for extra working hours. Whatever the situation, even after becoming fathers, men are expected to overinvest in work, while mothers are expected to overinvest in family and underinvest in work (Tremblay, 2012).

Although there is an increasing number of singles in many developed societies, including Quebec, it appeared important to analyze the impacts of various public policies, such as paternity and parental leave, which can make it possible for men and women to live as a couple but on their own terms (Beck, 1992). Indeed, various family policies such as parental and paternity leave could make this third solution possible. Our analysis of paternity and parental leave in Quebec shows that while this leave does make things better for some fathers and couples (Tremblay \& Lazzari Dodeler, 2015), our results show that there are important challenges related to timing and length of leave but also factors related to the impacts on fathers' careers.

\section{Disclosure statement}

No potential conflict of interest was reported by the authors.

\section{Notes on contributors}

Valérie Harvey is from Canada, but lived and worked in Japan. She has done her master in sociology (University Laval) about the status of women in Japan and conducted interviews to see how Japanese women can balance their lives with a challenging labor market. For her doctorate in sociology 
(University Laval), she studied the impacts of a new public program in the Quebec province, especially the consequences of the mandated five weeks of paternity leave.

Diane-Gabrielle Tremblay is a specialist in human resources management, economics and sociology of work. She holds a doctorate in economics from the University of Paris-I - Sorbonne and a postgraduate degree in sociology. She has been a professor at TÉLUQ since 1988. She holds the Research Chair on Socio-Organizational Issues in the Knowledge Economy since 2002 and has secured significant SSHRC funding for a CURA on age and social time management. She has also obtained numerous research grants from SSHRC, CEFRIO, the FQRSC and European organizations on topics related to work organization, teleworking, communities of practice, the articulation between work and family.

\section{ORCID}

Valérie Harvey (D) http://orcid.org/0000-0001-7751-2555

Diane-Gabrielle Tremblay (D) http://orcid.org/0000-0002-3343-9146

\section{References}

Bardin, L. (1993). L'analyse de contenu [content analysis]. Paris: Presses universitaires de France.

Beck, U. (1992). I am I': Gendered space and conflict inside and outside the family. In Risk society, towards a new modernity (pp. 103-126). London: Sage.

Brandth, B., \& Kvande, E. (in press). "Flexible use of parental leave for fathers - consequences for caregiving". In P. Moss, A.-Z. Duvander, \& A. Koslowski (Eds.), Parental leave and beyond: Recent developments, current issues, future directions. Bristol: Policy Press.

Carlson, D. S., Kacmar, K. M., \& Williams, L. J. (2000). Construction and initial validation of a multidimensional measure of work-family conflict. Journal of Vocational Behavior, 56(2), 249-276. doi:10. 1006/jvbe.1999.1713

Coltrane, S., Miller, E. C., DeHaan, T., \& Stewart, L. (2013). Fathers and the flexibility stigma. Journal of Social Issues, 69(2), 279-302.

Conseil de gestion de l'assurance-parentale. (2015). Rapport sur le portrait des prestataires du Régime québécois d'assurance parentale 2013 [Quebec Parental Insurance Program's Users Report 2013] Conseil de gestion de l'assurance parentale.

Conseil de gestion de l'assurance-parentale. (2016). Rapport annuel 2015 [Annual Report 2015]. Quebec: Gouvernement du Québec.

Conway, J. F. (2003). The Canadian family in crisis. Toronto: James Lorimer \& Company Ltd Publishers.

Daverth, G., Cassell, C., \& Hyde, P. (2016). The subjectivity of fairness: Managerial discretion and worklife balance. Gender, Work \& Organization, 23(2), 89-107.

Doucet, A., McKay, L., \& Tremblay, D.-G. (2009). Parental leave in Canada and Quebec: How to explain the different routes taken? In P. Moss, \& S. Kamerman (Eds.), The politics of parental leave policies. Bristol: Policy Press. Retrieved from http://catalogue.nla.gov.au/Record/4695544, 31-48

Employment Insurance Monitoring and Assessment Report. (2017). Employment insurance monitoring and assessment report for the fiscal year beginning April 1, 2015 and ending March 31, 2016, Government of Canada. Retrieved from https:/www.canada.ca/en/employment-socialdevelopment/programs/ei/ei-list/reports/monitoring2016.html

Esping-Andersen, G. (2009). The incomplete revolution: Adapting to women's new roles. Cambridge: Polity Press.

Forget, D. (2011). Le ras-le-bol des congés parentaux. Boss-partum". [Fed up with parental leave. Boss-partum]. Jobboom, 12(4), August. Retrieved from https://oraprdnt.uqtr.uquebec.ca/ Gscdepot/ped1035/49/ped1035_49_a00.pdf

Gíslason, I. V. (2007). Parental leave in Iceland, bringing the fathers in. Developments in the wake of new legislation in 2000: Powerpoint. Akureyri: Jafnréttisstofa.

Gíslason, I. V. (2011). Changing fathers - reluctant mothers? International Network on Leave Policies \& Research. 
Gíslason, I. V., \& Brandth, B. (2012). Family policies and the best interest of children. In Nordic Council of Ministers (Ed.), Parental leave, childcare and gender equality in the Nordic countries (pp. 109-145). Copenhague: Norden.

Government of Canada. (1970). Divorce Act, R.S. 1970, c. D-8. Ottawa: Government of Canada. Retrieved from http://laws-lois.justice.gc.ca/eng/acts/d-3.4/page-8.html\#h-16

Haas, L., \& Hwang, C. P. (2008). The impact of taking parental leave on fathers' participation in childcare and relationships with children: Lessons from Sweden. Community, Work \& Family, 11(1), 85104. doi:10.1080/13668800701785346

Harvey, V., \& Tremblay, D.-G. (in press). Quebec's fathers and their use of leave: Despite success, a few challenges appear. In P. Moss, A.-Z. Duvander, \& A. Koslowski (Eds.), Parental leave and beyond: Recent developments, current issues, future directions. Bristol: Policy Press.

Institut de la statistique du Québec. (2017). Travail et rémunération: État du marché du travail au québec - bilan de l'année 2016. In [Labor and earning: State of the labor market in Quebec review 2016] (pp. 25-40). Quebec: Gouvernement du Québec.

Lamb, M. E., \& Tamis-Lemonda, C. S. (2004). "The role of father: An introduction". In M. E. LAMB (Ed.), The role of the father in child development (pp. 1-31). Hoboken, NJ: John Wiley \& Sons.

Moen, P., Kelly, E. L., Fan, W., Lee, S., Almeida, D., Kossek, E. E., \& Buxtond, O. M. (2016). Does a flexibility/support organizational initiative improve high-tech employees' well-being? Evidence from the work, family, and health network. American Sociological Review, 81(1), 134-164. doi:10.1177/ 0003122415622391

Ramchandani, P. G., Domoney, J., Sethna, V., Psychogiou, L., Vlachos, H., \& Murray, L. (2012). Do early father-infant interactions predict the onset of externalising behaviours in young children? Findings from a longitudinal cohort study. Journal of Child Psychology and Psychiatry, 19 juillet, 1-9. doi:10.1111/j.1469-7610.2012.0258

Rudman, L. A., \& Mescher, K. (2013). Penalizing men who request a family leave: Is flexibility stigma a femininity stigma? Journal of Social Issues, 69(2), 322-340. doi:10.1111/josi.12017

Savall, H., \& Zardet, V. (2004). Recherche en sciences de gestion: approche qualimétrique [economics' contribution to HRM]. Paris: Economica.

Tanaka, S., \& Waldfogel, J. (2007). Effects of parental leave and work hours on fathers' involvement with their babies. Community, Work \& Family, 10(4), 409-426. doi:10.1080/13668800701575069

Tremblay, D.-G. (2012). Articuler emploi et famille. Le rôle du soutien organisationnel au cœur de trois professions [Reconciling work and family. Organizational support in three professional groups]. Quebec: Presses de I'Université du Québec.

Tremblay, D.-G. (2014). "Quebec's policies for work-family balance: A model for Canada?" in B. Fox (Ed.), Family patterns, gender relations (4th ed.) (pp. 535-551). Toronto: Oxford University Press.

Tremblay, D.-G. (2015). Emploi et gestion des ressources humaines dans l'économie du savoir [Work and human resource management in the knowledge economy]. Quebec: Presses de I'Université du Québec.

Tremblay, D.-G., \& Lazzari Dodeler, N. (2015). Les pères et la prise du congé parental ou de paternité: Une nouvelle réalité [Fathers and use of parental/paternity leave: $A$ new reality]. Quebec: Presses de I'Université du Québec.

Tremblay, D.-G., \& Mascova, E. (2013). Les avocates, les avocats et la conciliation travail-famille [Female and male lawyers and work-family balance]. Montréal: Les éditions du remue-ménage.

Tremblay, D.-G., \& Mascova, E. (2015). Conflict between professional engagement and temporal regimes of lawyers: The challenge of work-life permeability. Papers in Political Economy, 53, 1-18.

United Nations. (2011). Men in families and family policy in a changing world. New York: United Nations.

Williams, J. C., Blair-Loy, M., \& Berdahl, J. L. (2013). Cultural schemas, social class, and the flexibility stigma. Journal of Social Issues, 69(2), 209-234. doi:10.1111/josi.12012

Zins, Beauchesne et associés. (2014). Sondage auprès de pères salariés ayant eu recours au Régime québécois d'assurance parentale (RQAP) à la suite d'une naissance: Rapport final [Survey of working fathers who used the Quebec Parental Insurance Plan (QPIP)'s after a birth: Final report]. Québec: Conseil de gestion de l'assurance-parentale. 